\title{
Ramadhan dan Pertumbuhan Ekonomi Umat
}

\author{
Pratiwi Subianto, S.E.,M.E. \\ Universitas Nahdlatul Ulama Kalimantan Selatan \\ Pratiwi.Subianto@unukase.ac.id
}

Hiruk pikuk bulan ramadan mulai dirasakan oleh umut muslim di seluruh dunia. Tidak terkecuali di Indonesia, berbagai persiapan sudah mulai di lakukan masyarakat menjelang tibanyanya bulan yang dipenuhi berbagai kemuliaan ini. Mulai dari mempersiapkan berbagai keperluan dapur seperti stok sembako sampai dengan berbagai perlengkapan ibadah laianya. Bagi masyarakat muslim di Indonesia bulan ramadan sangat istimewa, ibarat tamu ia adalah tamu yang sangat istimewa.

Dalam kegiatan ekonomi kemasyarakatan secara umum, datangnya bulan Ramadan juga berdampak positif, diantaranya banyak bermunculan penjual berbagai kebutuhan pokok, baik berupa jajanan untuk berbuka puasa dan sahur, yang ditandai dengan maraknya pesanan dalam bentuk kotakan diberbagai tempat makan, adalagi bermunculan berbagai pasar wadai /kue menjelang ngabuburit (berbuka puasa) selain itu juga banyak permintaan berbagai komoditas perlengkapan ibadan, seperti baju, sarung, mushap al-quran dan yang lainya yang terus mengalami trend kenaikan.

Pola ekonomi dibulan ramadan ini juga berdampak signifikan pada aspek ekonomi umat, khususnya ekonomi muslim. Karena banyak produk halal yang dipasarkan oleh berbagai produsen guna menunjang keperluan masyarakat dibulan puasa. Seperti kurma, madu, susu dan yang laianya. Yang secara tidak langsung memberi suntikan modal yang terus berputar dalam upaya kegiatan ekonomi kerakyatan, khususnya ekonomi umat dan kerakyatan. Sudah bisa dipastikan hal ini akan berlanjut sampai hari lebaran tiba, dimana masyarakat muslim yang merantau, akan pulang ke kampung halaman untuk bersilaturahim kepada keluaraga tercinta. Sebuah tradisi budaya yang sudah diwariskan nenek moyang kita menjelang idul fitri tiba ialah berkunjung kepada sanak famili untuk bersilaturahim. Hal inilah yang menjadi kekuatan ekonomi, dimana perputaran uang itu akan senantiasa beredar diantara para pengusaha muslim itu sendiri, yang pada akhirnya kekuatan ekonomi umat. 
Tidak bisa dipungkiri, banyaknya kandungan hikmah puasa di bulan Ramadan bagi kaum muslimin yang menjalankannya, membuat keteraturan pola hidup yang seharusnya bisa terus di jalankan di luar ramadan. Hal ini menjadi titik tolak untuk menuju perubahan yang besar yakni menjadi bangsa yang besar, karena semua potensi sudah kita miliki. mulai dari jumlah muslim terbanyak di dunia, Sumber daya yang kita punya, Aspek letak geografis negara dan faktor pendukung lainya. Hal ini hendaknya berjalan lurus dengan tingkat pertumbuhan ekonomi. Kita bukan lagi sebagai negara pengimpor melainakn kita sebagai bangsa yang mengeksport berbagai keperluan kaum muslim diseluruh dunia. Karena kita memiliki kekuatan dan potensi yang menunjang, tinggal di kelola dan di maksimalkan secara lebih profesional. 